\title{
PENGARUH PERSEPSI REMAJA TENTANG KONFLIK ANTAR ORANG TUA DAN RESILIENSI TERHADAP DEPRESI DAN KECEMASAN
}

\author{
Mutingatu Sholichah \\ Fakultas Psikologi Universitas Ahmad Dahlan, Jl. Kapas no 9 Yogyakarta \\ mutiafay@yahoo.com
}

\begin{abstract}
Abstrack
The family plays a very important role in the development of children and adolescents, but not all families can provide an enabling environment for children to grow and develop optimally, such as family tinged conflicts between parents. This study was intended to findout the effects of adolescents perception about interparental conflict on anxiety and depression and the role of resilience to mediate those effects. Participants were 102 junior and senior highs school students aged 12-17 years old, who completed four scales used as instruments in the study: T-Mas anxiety scale from Taylor, Kurcher Adolescent Depression Scale (KADS ) 11 items version, The Resilience Scale developed by Wagnild \& Young, and The Children's Perception of Interparental Conflict Scale (The CPIC) from Grych dan Finchman. Data obtained from 4 scales were analyzed with Path analysis. The findings indicated all hypotheses were accepted, that The Children's Perception on Interparental Conflict shows a direct significant effect on anxiety as well as depression but the effect was not significant when mediated by resilience. Resilience plays an important role to protect adolescence from adversity resulted from interparental conflict.
\end{abstract}

Key words: anxiety, depression, internalizing problem,resilience

\begin{abstract}
Abstrak
Keluarga memainkan peran yang sagat penting dalam perkembangan anak dan remaja, namun tidak semua keluarga dapat memberikan situasi yang kondusif bagi anak untuk tumbuh kembang secara optimal, misalnya keluarga yang diwarnai konflik antar orang tua. Penelitian ini bertujuan untuk mengungkap pengaruh Persepsi remaja tentang konflik yang dialami oleh orangtuanya terhadap depresi dan kecemasan sebagai bentuk internalizing problems pada remaja, serta mengungkap peran resiliensi sebagai faktor mediasi. Partisipan penelitian adalah 102 Siswa-siswi dari dua sekolah menengah di Yogyakarta berusia 12-17 tahun. Alat ukur yang digunakan diadaptasi dari Skala kecemasan T-Mas yang dikembangkan oleh Taylor, skala depresi KADS (Kurcher Adolescent Depression Scale) versi 11, The Resilience Scale yang dikembangkan Wagnild \& Young, serta skala The Children's Perception of Interparental Conflict Scale (The CPIC) yang dikembangkan oleh Grych dan Finchman. Data dianalisis dengan menggunakan analisis jalur (path analysis). Hasil menunjukkan persepsi tentang konflik antar orangtua terbukti memiliki pengaruh langsung yang signifikan baik terhadap kecemasan maupun depresi. Pengaruh tersebut
\end{abstract}


menjadi tidak signfikan ketika dimediasi oleh resiliensi. Resiliensi memainkan peran penting dalam menurunkan efek negatif yang diakibatkan oleh konflik antar orangtua.

Kata kunci: depresi, kecemasan, internalizing problem, resiliensi

\section{Pendahuluan}

Keluarga yang sentral dalam kehidupan setiap orang. Keluarga memiliki peran yang paling penting dalam kaitannya dengan perkembangan psikologis individu, interaksi emosional dan pemeliharaan harga diri (Ritvo \& Glick, 2002), sesuai dengan pendapat Berns (2004) bahwa keluarga merupakan tempat yang menyediakan pengasuhan, afeksi dan berbagai kesempatan yang akan menjadi sarana sosialisasi anak yang utama bagi anak-anak dan memberikan pengaruh yang paling signifikan bagi perkembangannya. Sehingga untuk mencapai kondisi tersebut diperlukan ikatan kuat yang tidak dapat diperoleh dari situasi di luar keluarga. Menurut Ritvo \& Glick (2002) anggota keluarga biasanya memiliki saling keterikatan yang intens dan berlangsung dalam jangka panjang yang berakar dari pengalaman masa lalu, peran sosial, dukungan, kebutuhan dan harapan. Faktor-faktor tersebutlah yang terus-menerus bekerja untuk menjaga sistem keluarga tetap seimbang dan melindungi dari perubahan terlalu yang terlalu besar atau cepat.

Keluarga seringkali harus menghadapi berbagai tuntutan kekuatan yang dapat menimbulkan ketidakseimbangan (disequilibrium), sehingga harus merespon tuntutan tersebut dengan melakukan perubahan agar dapat mengembalikan keseimbangan yang bersifat stabil (homeostasis). Ketidakseimbangan dapat terjadi pada setiap keluarga sehingga Berns (2004) menggambarkan pelaksanaan fungsi keluarga dalam rentang antara sehat (fungsional) dan tidak sehat (disfungsional) yang bersifat kontinum. Sifat kontinum menunjukkan bahwa kondsi keluarga bersifat dinamis, sehingga tidak ada keluarga yang dikatakan 'sehat' sepanjang waktu, karena masalah dan konflik sangat mungkin terjadi pada setiap keluarga, namun demikian penyelesaan konflik yang menentukan bagaimana pelaksanaan fungsi keluarga. Cumming \& Davies (Grych \& Fincham, 2001) menyatakan ada kalanya adu argumentasi dalam menyelesaikan konflik merupakan cara berkomunikasi dan merupakan hal bersifat produktif bagi sebuah keluarga, namun ketika diantara kedua orangtua dalam keluarga mengalami konflik yang lebih banyak, lebih intens, dan berlangsung lama, maka akan meningkatkan risiko untuk terbentuknya masalah emosional dan perilaku bagi anggota keluarga tersebut. Ritvo \& Glick (2002) menyatakan bahwa pada keluarga yang fungsional terdapat proses pemecahan masalah dan resolusi konflik yang efektif, sedangkan pada keluarga yang mengalami disfungsi, penyelesaian konflik yang gagal menjadi salah satu latar belakang terjadinya masalah dalam keluarga.

Kemampuan orangtua dalam menyelesaikan konflik memiliki peran sangat penting dalam kehidupan anak. Esfandyary, Baharudin, dan Nowzari ( 2009), menyatakan bahwa anak-anak dan remaja sangat terpengaruh oleh kondisi hubungan diantara kedua orangtuanya. Bila dalam keluarga terdapat konflik diantara kedua orangtuanya, maka anak-anak seperti 
'terjepit' diantara kedua orangtuanya. Menyaksikan ekspresi kemarahan dan konflik dapat menimbulkan efek merugikan bagi anak-anak yang berkaitan dengan meningkatnya distres, agresi dan mudah terpicu secara emosonal, masalah penyesuaian dalam jangka panjang termasuk masalah perilaku, emosional, sosial dan akademik (Cummings dan Davies, dalam Grych \& Fincham, 2001).

Esfandyary, Baharudin, dan Nowzari, (2009) mengidentikkan istilah konflik antar orangtua dengan kekerasan yang terjadi diantara kedua figur orangtua, karena mengaitkan dengan tingginya kasus kekerasan dalam rumah tangga yang menjadi latar belakang terjadinya konflik antar orangtua. Diperkirakan di seluruh dunia $33 \%$ perempuan telah menjadi korban kekerasan dalam rumah tangga (KDRT) dan menyaksikan kekerasan dalam rumah tangga menjadi ancaman utama bagi perkembangan anak (Heise, Ellsberg, and Gottemoeller, dalam Gelles, 2011). Sedangkan Buehler, Krishnakumar, Anthony, Tittsworth, \& Stone (2011) mendefinisikan konflik antar orangtua sebagai ketidaksepakatan diantara kedua orangtua tentang berbagai hal yang terjadi dalam keluarga. Gottman (Harvey \& Wenzel, 2002) menyatakan konflik antar pasangan dapat bermakna negatif, atau positif bagi fungsi dan hubungan dalam keluarga, tergantung pada cara menyelesaikan konflik yang terjadi. Respon emosional anak akan menentukan apakah konflik antar orangtua dianggap bersifat konstruktif, yaitu membawa efek positif bagi perkembangan keluarga atau destruktif (membawa efek negatif bagi perkembangan keluarga). Cumming (Harvey \& Wenzel, 2002) menemukan adanya hubungan antara konflik antar orangtua yang bersifat destruktif dengan distres dan masalah dalam penyesuaian yang dialami anak.
Buehler et al. (Gullotta \& Adams, 2005) membedakan pengertian konflik antar orangtua dari dua sisi yaitu konflik yang terbuka (overt) dan konflik tertutup (covert). Konflik terbuka merupakan perasaan atau perilaku bermusuhan yang mengindikasikan hubungan yang negatif diantara kedua orangtua. Konflik tertutup merupakan perasaan dan perilaku bermusuhan yang merupakan manifestasi secara tidak langsung dari adanya konflik diantara kedua orangtua (Buehler \& Trotter, dalam Gullotta \& Adams, 2005) misalnya berusaha membuat anak berpihak ke salah satu orangtua, merendahkan pasangan di hadapan anak.

Efek negatif konflik antar kedua orangtua ditemukan dari berbagai penelitian. Hasil penelitian yang dilaporkan oleh Grych \& Fincham (2001) menunjukkan adanya hubungan antara konflik orangtua dengan indikasi mal-adjustment seperti masalah perilaku yang bersifat internal (misalnya: depresi, kecemasan) dan masalah perilaku yang bersifat eksternal (misalnya: perilaku agresif), gejala PTSD, gejala gangguan fisiologis dan kesehatan, gangguan mood, masalah dalam bidang akademis, hubungan dengan teman sebaya dan rendahnya kemampuan problem solving sosial. Demikian pula hasil penelitian Cumming, et.al., (Grych \& Fincham, 2001) yang mengungkap respon anak dalam situasi nyata maupun hasil studi analog yang dilakukan oleh Davis, Hops, \& Sheeber ( Grych \& Fincham, 2001), menunjukkan anak merespon situasi pertengkaran orangtua dengan menunjukkan emosi negatif, perubahan yang bersifat fisiologis dan perasaan tidak nyaman (discomfort). Davies dan Windle (Grych \& Fincham, 2001) melaporkan bahwa pada tahap perkembangan remaja, konflik keluarga menjadi prediktor yang lebih kuat terhadap 
kenakalan remaja dan masalah penggunaan alkohol pada remaja perempuan, kerentanan pada remaja perempuan juga terjadi untuk problem yang bersifat internal misalnya gejala depresi, kecemasan dan masalah emosional lainnya, seperti rasa takut, perasaan tidak berdaya, self esteem yang rendah

Konflik antar orangtua dalam intensitas tinggi akan meningkatkan resiko berkembangnya masalah internal pada anak dan remaja, karena konflik antar orangtua dapat menimbulkan dampak yang bersifat emosional (Esfandyary, Baharudin dan Nowzari, 2009b). Keberadaan konflik antar orangtua dikaitkan dengan berkembangnya berbagai problem yang bersifat internal seperti kecemasan, depresi, rasa takut, perasaan tidak berdaya, self esteem yang rendah dan rendahnya perilaku sosial pada anak dan remaja. Hasil penelitian Davern, Staiger \& Luk (2005) menunjukkan remaja dan orangtua memiliki persepsi yang tidak bebeda tentang konflik antar orangtua; namun persepsi remaja tentang konflik antar kedua orangtuanya menjadi prediktor yang signifikan terhadap penyesuaian dirinya sedangkan persepsi orangtua remaja tidak berkonribusi terhadap penyesuaian diri remaja. Hasil tersebut menunjukkkan bahwa remaja mempersepsikan efek dari konflik orangtuanya dengan cara yang berbeda dengan orangtuanya

Persepsi merupakan interpretasi pada hal-hal yang diindera oleh seseorang (Solso, Maclin \& Maclin, 2008), sehingga dalam konteks konflik antar orangtua, maka remaja memproses kejadian-kejadian sensorik berupa konflik antar orang tua dan memaknainya sesuai pengetahuan yang didapatkan dari pengalamannya. Hasil penelitian Grych, Seid, \& Fincham (1992) menunjukkan dinamika persepsi remaja tentang konflik antar orangtua yang memunculkan masalah internal. Situasi konflik dalam keluarga menumbuhkan perasaan terancam dan perasaan tidak mampu untuk melakukan koping terhadap konflik tersebut, mereka menyalahkan diri sendiri terutama bila isi konflik berkaitan dengan anak dan remaja, sehingga kondisi tersebut membuat anak/remaja mengembangkan problem internal seperti kecemasan atau depresi

Dalam taraf tertentu reaksi kecemasan merupakan hal yang wajar dalam kaitannya dengan upaya perahanan diri manusia, sebagaimana yang dikatakan Connolly, Simpson \& Petty (2006) bahwa perasaan takut dan khawatir pada anak, remaja dan orang dewasa merupakan hal yang normal dari perkembangan manusia. Hal yang senada dikatakan oleh Noyes \& Hoehn-Saric (2013) bahwa kecemasan dalam tingkat rendah dapat membantu untuk melakukan koping terhadap hambatan, namun kecemasan dalam tingkat tinggi, dapat menyebabkan kekacauan (disorganisasi). Kecemasan dikatakan menjadi abnormal, ketika durasi dan intensitasnya tidak proporsional dengan potensi untuk terjadinya ancaman, terjadi pada situasi yang tidak membahayakan atau tidak ada ancaman yang dikenali. Hamilton (McDowell, 2006) membedakan kecemasan ke dalam 2 kategori yaitu (1) kecemasan sebagai suatu bentuk reaksi yang normal terhadap bahaya; yang sifatnya lebih ringan namun berlangsung lebih lama dibandingkan ketakutan biasa dan membutuhkan perubahan biologis yang berguna untuk mengelola stres (2) kecemasan sebagai suasana hati (mood) yang patologis yaitu reaksi yang muncul bukan karena ancaman dari luar, namun dari dalam dirinya sendiri.

Kecemasan muncul sebagai respon terhadap ancaman bahaya atau tantangan terutama yang dinilai tidak dapat dikontrol, yang mengakibatkan kegoyahan dalam 
struktur kognitif dan afektif, yang disertai ketakutan dan kesiapan fisik untuk menghadapi peristiwa negatif yang akan datang. Komponen afektif dapat dalam bentuk perasaan tak berdaya karena merasa tidak mampu untuk memprediksi atau mengontrol peristiwa diantisipasi (Mc. Dowell, 2006).

Durand \& Barlow (2003) menyatakan kecemasan merupakan kondisi mood yang berorientasi pada masa yang akan datang yang ditandai rasa takut karena ketidakmampuan memprediksi atau mengontrol kejadian yang akan datang. Sedangkan ketakutan merupakan reaksi segera terhadap bahaya yang terjadi saat itu dan ditandai tendensi yang kuat untuk melarikan diri sehingga memacu bagian simpatetik dari sistem syaraf otonom.

Tanda-tanda yang biasa dialami dalam kecemasan antara lain adanya tegangan emosional yang ditandai gejala dengan nyeri dada, jantung berdebar-debar, nafas tersengal-sengal, pikiran yang mengganggu tentang penyakit yang mungkin terjadi, merasa tidak normal, ragu-ragu karena merasa terancam, merasa yakin menghadapi ancaman yang nyata, potensi untuk melakukan koping terhadap masalah menjadi menurun (Stein, Hollander, dan Rothbaum, 2009). Manifestasi gejala kecemasan yang cukup kompleks dikemukakan pula oleh Noyes dan Hoehn-Saric (2013), yang menyatakan bahwa kecemasan merupakan pengalaman yang kompleks yang meliputi manifestasi yang bersifat psikis, somatik dan hyperarousal, yaitu meliputi respon yang dirasakan secara fisik dan kondisi mudah terbangkit secara fisiologis. Manifestasi psikis terdiri dari reaksi afektif, yaitu kondisi tegang, ketakutan hingga kondisi yang ekstrem berupa panik. Manifestasi pada aspek kogitif ditandai dengan kegelisahan untuk menyesuaikan diri dengan situasi dan ketidakpastian di masa yang akan datang, khawatir, antisipasi bencana, takut tidak mampu menyesuaikan diri dengan lingkungan, takut menjadi terlalu cemas sehingga mempermalukan diri sendiri di depan publik.

Taylor (McDowell, 2006; International Encyclopedia of the Social Sciences, 2012) meninjau kecemasan berdasarkan teori dari Hull bahwa individu yang dengan tingkat kecemasan yang tinggi akan menunjukkan performansi yang lebih baik ketika dihadapkan pada tugas yang sederhana sedangkan individu dengan kecemasan rendah akan menunjukkan performansi yang lebih baik ketika dihadapkan pada tugas yang kompleks.

Berdasarkan teori Hull tersebut Taylor (McDowell, 2006) mengembangkan The Manifest Anxiety Scale yang beranggapan bahwa kecemasan dapat diketahui dari tingkat dorongan yang akan direfleksikan dalam intensitas kecemasan yang manifes, yaitu kecemasan yang nyata dan dirasakan oleh individu. Hasil pengukuran skala kecemasan menunjukkan individu yang memiliki dorongan yang lebih tinggi atau kecemasan yang termanifestasi, menunjukkan performansi yang lebih baik ketika dihadapkan pada tugas-tugas yang mudah, namun menunjukkan performansi yang lebih rendah ketika dihadapkan pada tugas-tugas yang kompleks. (McDowell, 2006).

Berlainan dengan kecemasan yang berorientasi pada ancaman yang akan datang yang dapat diantisipasi, maka menurut Davey \& Wells (2006) individu yang mengalami depresi menunjukkan durasi gangguan yang lebih lama, lebih sulit dikelola, lebih sulit diatasi, kurangnya hasrat dan usaha untuk mengatasi, memiliki keyakinan yang lebih rendah untuk bisa mengatasi gangguan dan lebih berorientasi pada masa lalu. Oleh 
karena itu Beck (Beck dan Alford, 2009) mengatakan bahwa gambaran yang bersifat paradoks (bertolak belakang) ditemukan pada individu yang mengalami depresi, yaitu di sau sisi tersiksa dengan pikiranpikiran irasional yang merendahkan dirinya namun menolak bukti-bukti objektif atau logis yang berlawanan dengan pikirannya yang irasional tersebut.

Verduyn, Rogers, \& Wood (2009) menyatakan batasan depresi digunakan untuk mendeskripsikan sekelompok simptom yang melibatkan perubahan yang signifikan pada mood, pikiran dan aktivitas, yang berlangsung lama dan menyebabkan perubahan dalam fungsi-fungsi personal dan sosial, berlangsung lebih dari 2 minggu. Suasana hati yang depresif dapat disertai dengan tangisan, kesedihan dan atau kondisi mudah tersinggung yang disertai kehilangan kegembiraan dalam melakukan aktivitas sehari-hari. Wicks-Nelson dan Israel (2006) menyatakan bahwa pada anakanak dan remaja, depresi seringkali disertai gangguan lain seperti kecemasan, gangguan perilaku, gangguan sikap menentang dan penyalahgunaan alkohol dan berbagai zat pengganti.

Kurcher (2009) mengemukakan pengertian depresi klinis untuk membedakannya dengan istilah depresi yang biasa digunakan secara umum untuk menggambarkan reaksi umum terhadap berbagai peristiwa dalam kehidupan. Depresi klinis adalah suatu kondisi medis yang ditandai adanya kontrol yang dilakukan oleh pikiran (otak) yang mempengaruhi suasana hati yang mengakibatkan munculnya sejumlah simtom (gejala) yang dirasakan individu dan tanda (sign) yang dilihat oleh orang lain, sehingga berdasarkan simtom dan sign tersebut ditentukan diagnosis medis berdasarkan pedoman klasifikasi internasional seperti DSM dan ICD. Depresi ditandai oleh sejumlah gangguan yang memiliki dampak negatif pada kehidupaan individu, seringkali disertai dengan kecemasan, dan masalah yang berhubungan dengan keluarga, pekerjaan atau sekolah.

Kurcher(2009) merujuk pada pedoman diagnostik DSM-IV untuk menggambarkan 3 gejala utama diantara 5 gejala yang harus terpenuhi untuk menegakkan diagnosis depresi yaitu (1) suasana hati sedih (depressed mood), (2) kehilangan minat atau kegembiraan atau pada anak-anak adalah suasana hati yang mudah marah dan (3) gejala berlangsung setidaknya selama 2 minggu. Gejala lain adalah: meningkatnya atau menurunnya berat badan tanpa adanya diet, insomnia atau hipersomnia, agitasi atau retardasi psikomotorik, perasaan lelah atau tak bertenaga, perasaan bersalah atau tak berharga, ragu-ragu atau sulit konsentrasi, memikirkan, merencanakan atau tindakan untuk bunuh diri.Gejala depresi dapat berbeda pada orang dewasa dan anak-anak. Gejala depresi pada anak lebih sulit untuk diidentifikasi (Kurcher, 2009). Oleh karena itu banyak dikembangkan alat ukur depresi yang spesifik digunakan untuk anak dan remaja.

Selain kecemasan dan depresi, beberapa penelitian menemukan konflik keluarga menimbulkan efek negatif yang meluas pada berbagai aspek kehidupan anak (Grych \& Fincham, 2001), yang dapat berlanjut sampai masa dewasa. Segal, Coolidge \& Roswsky (2006) menjelaskan bahwa pengalaman buruk pada masa anak seperti kondisi keluarga yang kacau, terbukti menjadi faktor resiko terjadi gangguan kepribadian pada masa dewasa.

Telah dikemukakan berbagai hasil penelitian yang menunjukkan bahwa konflik antar orangtua menjadi faktor resiko bagi terjadinya berbagai masalah pada anak dan remaja dalam berbagai variasi bentuknya, 
namun ada perbedaan efek konflik antar orangtua terhadap anak-anaknya. Menurut Wicks-Nelson dan Israel (2006) prinsip multi-finalitas merupakan suatu pengalaman dapat berfungsi secara berbeda-beda tergantung pada berbagai pengaruh yang menyebabkan perbedaan hasil akhirnya. Implikasi dari prinsip tersebut adalah suatu pengalaman yang bersifat negatif dapat mendatangkan faktor resiko yang mengarah terjadi berbagai masalah internal (internalized problems) dan masalah eksternal (externalized problems) namun dapat pula menumbuhkan faktor protektif yang menjadikan individu untuk tumbuh menjadi pribadi yang memiliki keberanian untuk tumbuh dalam situasi yang sulit.

Kesulitan atau ancaman merupakan kejadian yang potensial untuk menghambat fungsi normatif dan menyebabkan efek yang bersifat negatif (Riley \& Masten dalam Peters, Leadbeater \& McMahon, (2005) misalnya anak-anak yang tumbuh dalam keluarga yang penuh konflik atau kekerasan, mengalami kekerasan seksual, dan pengalaman buruk lainnya. Kesulitan atau ancaman tesebut menjadi suatu faktor resiko, yaitu suatu karakteristik yang memprediksi hasil negatif atau meningkatkan kemungkinan untuk mengalami hasil yang tidak diinginkan. Resiliensi terjadi ketika resiko atau ancaman serius terhadap perkembangan $\&$ fungsi yang sehat, justru menghasilkan efek yang positif.

Menurut Masten (Wicks-Nelson dan Israel, 2006) resiliensi merupakan kondisi tidak adanya atau rendahnya tingkat psikopatologi pada saat individu dihadapkan pada ancaman yang serius. Hal tersebut dimungkinkan karena resiliensi merujuk pada karakteristik atau kemampuan individu untuk melakukan koping dengan sukses terhadap berbagai perubahan atau hambatan, sehingga Individu yang memiliki resiliensi merasa percaya diri, mengetahui kekuatan dan keterbatasan dirinya (Wagnild \& Young , dalam Henderson \& Milstein, 2003)

Newman (Glover, 2006) menekankan arti penting resiliensi yang tidak terbatas untuk menyelamatkan individu dalam lingkungan yang bermasalah namun juga memungkinkan individu untuk tumbuh dan berkembang. Dengan demikian faktor resiliensi dapat berperan sebagai mediator antara stresor dan psikopatologi, sebagaimana dapat dilihat pada gambar 1 yang menggambarkan relasi antara peristiwa yang tidak menyenangkan dalam kehidupan individu (berperan sebagai stresor) dengan psikopatologi. Stresor memicu berbagai proses dalam diri individu yang bersifat biologis, psikologis dan sosial yang dapat beperan sebagai mediator antara stresor dengan psikopatologi. Karakteristik individu dalam relasi antara stresor dengan psikopatologi dapat pula dimoderasi oleh karakteristik individu atau faktor lingkungan. Dengan demikian pengaruh stresor terhadap psikopatologi tidak bersifat langsung, karena ada variabel moderator dan mediator yang berperan sebagai peredam yang memperingan psikopatologi. 


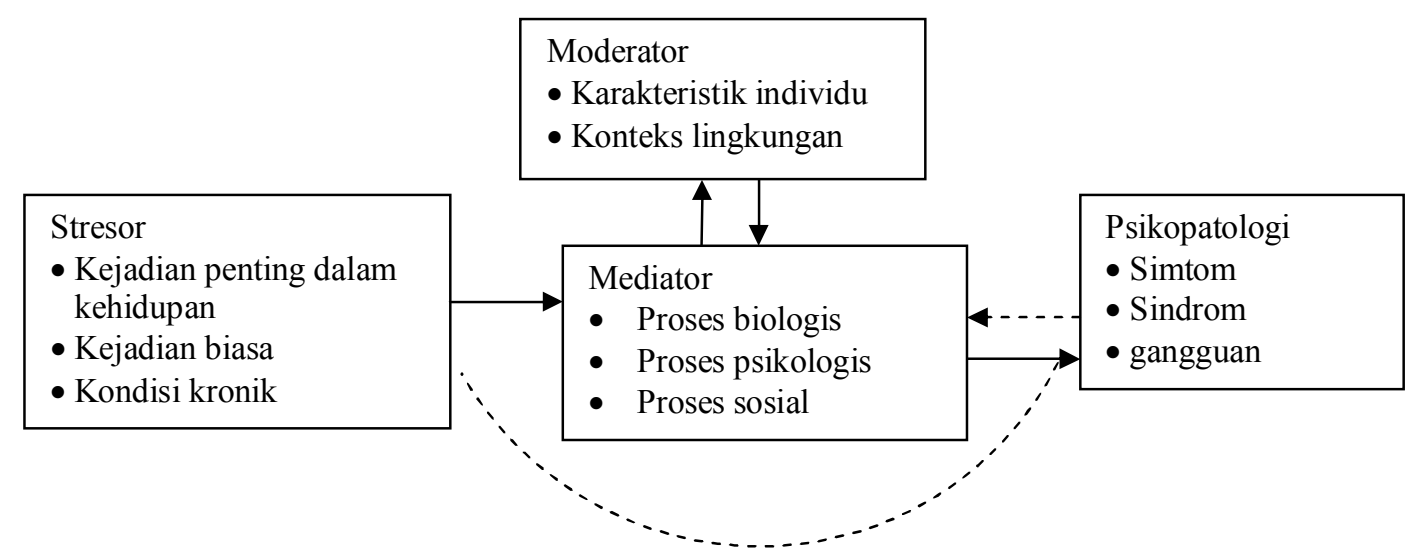

Gambar 1. Model hubungan antara stresor dan psikopatologi menurut Grant, et al.

(Wicks-Nelson dan Israel, 2006, p.25)

Menurut Henderson \& Milstein (2003) orang dewasa dan anak-anak yang memiliki resiliensi, ternyata menunjukkan karakteristik yang tidak berbeda. Bernard (Henderson \& Milstein, 2003), menyatakan anak-anak yang memiliki resiliensi menunjukkan karakteristik adanya kompetensi sosial yang disertai dengan kemampuan problem solving yang baik, berfikir kritis, kemampuan untuk mengambil inisiatif, memiliki tujuan, mampu melihat ke depan dan melihat hal-hal positif untuk dirinya di masa depan. Wagnild \& Young (Resnick, Roberto, \& Gwyther, 2011) mengidentifikasi 5 karakteristik resiliensi yaitu (1) self reliance yaitu keyakinan tehadap dirinya sendiri dan pengetahuan bahwa dia memiliki kekuatan personal (2) Spirituality atau meaningfulness yaitu realisasi bahwa hidup yang bertujuan (3) Equanimity yaitu cara pandang yang seimbang antara kehidupan dan pengalaman (4) Perseverance yaitu tetap teguh meskipun menghadapi kesulitan atau kekecewaan (5) Existential aloneness: pemahaman bahwa setiap orang adalah unik, dan meskipun banyak pengalaman yang dapat dijalani bersama orang lain, namun ada pula yang harus dihadapi sendirian.
Peran resiliensi dapat dilihat dari hasil beberapa studi, antara lain studi longitudinal di Hawaii yang menunjukkan para partisipan penelitian yang mengalami faktor resiko yang kronik yang berasal dari variabel keluarga dan kemiskinan, mayoritas mengalami berbagai bentuk masalah, namun sepertiga diantaranya berhasil mengatasi masalahnya pada masa remaja akhir, mereka adalah partisipan yang menunjukkan resiliensi yang tinggi (Wicks-Nelson dan Israel, 2006). Hasil penelitian tersebut menunjukkan peran resiliensi sebagai mediator antara stresor dan psikopatologi. Penelitian lain dikemukakan oleh Masten \& Powell (Luthar, 2003) menemukan pada anak-anak beresiko di Cambodia, bahwa akibat buruk dari kerentanan dapat diturunkan dengan meningkatkan faktor protektif yang berlaku seperti 'airbag' dalam kecelakaan mobil atau antibiotik yang melindungi dari infeksi. Beardslee \& Podorefsky (Luthar, 2003) mengemukakan hasil penelitiannya yang dilakukan pada sekelompok anak-anak yang orangtuanya mengalami depresi, namun anak-anaknya menunjukkan resiliensi yang ditunjukkan melalui karakteristik adanya pemahaman diri (self understanding) yang tinggi termasuk 
kesadaran tentang kondisi orangtuanya, secara psikologis mampu mengambil jarak terhadap masalah di keluarganya, mampu terlibat secara mendalam dengan sekolah dan kegiatan ekstra kurikuler.

\section{Metode Penelitian}

Subjek penelitian terdiri dari 122 siswa SMP dan SMA yang berumur 1217 tahun, namun data dari 20 subjek dinyatakan tidak layak untuk dianalisis berdasarkan kurang lengkapnya data yang dilaporkan. Dengan demikian data penelitian diperoleh dari pengukuran pada 102 subjek. Instrumen penelitian terdiri dari skala persepsi anak tentang konflik antar orang tua, skala resiliensi, skala kecemasan dan skala depresi untuk remaja. Skala Persepsi anak tentang konflik antar orang tua yang diadaptasi dari The Children's Perception on Interparental Conflict Scale yang dikembangkan oleh Grych dan Fincham. Skala terdiri 49 aitem. Hasil uji validitas menunjukkan sebanyak 30 item sehingga tersisa 19 item yang dinyatakan valid dengan skor korelasi item-total $\left(\mathrm{r}_{\mathrm{it}}\right)$ berkisar dari : 0,309- 0,550. Hasil uji reliabilitas menujukkan koefisien Cronbach's Alpha = 0,838 . Skala resiliensi diadaptasi dari skala yang dikembangkan oleh Wagnild \& Young yang terdiri dari 26 item dengan pilihan jawaban menggunakan model Likert. Hasil uji validitas menunjukkan diantara 26 item, dinyatakan gugur sebanyak 12 item sehingga tersisa 14 item yang dinyatakan valid dengan skor korelasi item-total $\left(\mathrm{r}_{\mathrm{it}}\right)$ berkisar dari : 0,309 - 0,535 sedangkan hasil uji reliabilitas menujukkan koefisien Cronbach's Alpha $=$ 0,771. Taylor Manifest Anxiety Scale (Tes T-MAS) merupakan skala kecemasan yang diadaptasi dari skala yang dikembangkan oleh Taylor pertama kali di tahun 1950. Skala terdiri dari yang terdiri dari 50 aitem yang memiliki pilihan jawaban yang bersifat dikotomis, yaitu jawaban 'ya' dan 'tidak'. Hasil uji validitas menunjukkan diantara 50 item, dinyatakan gugur sebanyak 18 item sehingga tersisa 32 item yang dinyatakan valid dengan skor korelasi item-total $\left(\mathrm{r}_{\mathrm{it}}\right)$ berkisar dari : 0,254 - 0,558, sedangkan hasil uji reliabilitas menunjukkan koefisien Cronbach's Alpha $=0,849$. Skala depresi untuk remaja KADS diadaptasi dari Kurcher Adolescent Depression Scale (KADS) yang dikembangkan oleh Kurcher tahun 2002. Skala depresi terdiri dari 11 aitem yang tiap memiliki 4 tingkat sekor, dari 1 sampai dengan 4. Hasil uji validitas menunjukkan diantara 11 item, dinyatakan gugur sebanyak 2 item sehingga tersisa 9 item yang dinyatakan valid dengan skor korelasi item-total $\left(\mathrm{r}_{\mathrm{it}}\right)$ berkisar dari : 0,261 - 0,579; sedangkan hasil uji reliabilitas menujukkan koefisien Cronbach's Alpha = 0,775.

Tabel 1. Rangkuman hasil uji validitas dan reliabilitas instrumen penelitian

\begin{tabular}{|c|c|c|c|c|c|}
\hline \multirow[t]{2}{*}{ skala } & \multirow[t]{2}{*}{$\mathrm{N}$} & \multicolumn{3}{|c|}{ Jumlah item } & \multirow{2}{*}{$\begin{array}{c}\text { Cronbach's } \\
\text { Alpha }\end{array}$} \\
\hline & & awal & valid & rit & \\
\hline KecemasanT-Mas & 102 & 50 & 32 & $0,254-0,558$ & 0,849 \\
\hline Depresi KADS & 102 & 11 & 9 & $0,261-0,579$ & 0,775 \\
\hline Resiliensi & 102 & 26 & 14 & $0,309-0,535$ & 0,771 \\
\hline $\begin{array}{l}\text { Persepsi tentang } \\
\text { konflik antar } \\
\text { orangtua }\end{array}$ & 102 & 49 & 19 & $0,309-0,550$ & 0,838 \\
\hline
\end{tabular}

\section{Hasil dan Pembahasan}

Data yang diperoleh dalam penelitian ini berupa data kuantitatif yang dianalisis dengan teknik statistik inferensial Analisis jalur (Path Analysis) untuk mengetahui peran antara Persepsi Anak Tentang Konflik Antar Orangtua dan resiliensi dalam memprediksi tingkat kecemasan, depresi. Analisis data dilakukan dengan bantuan program statistik SPSS versi 17.dan program Lisrel versi 8.80 (student Edition) oleh Jöreskog \& Sörbom 
untuk olah data dengan teknik analisis jalur. jalur (path analysis) dengan diagram jalur Analisis data menggunakan analisis seperti tertera dalam gambar berikut.

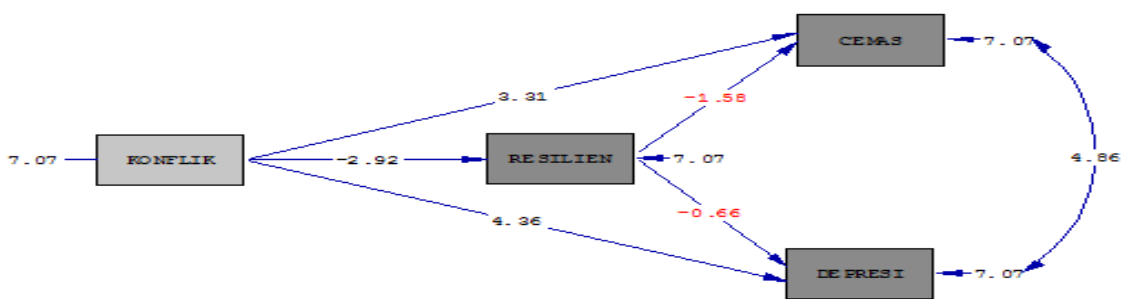

Chi-Square $=0.00, d f=0, P-$ value $=1.00000$, RMSEA $=0.000$

Gambar 2. Model hubungan antar variabel dalam analisis jalur

Hipotesis pertama dalam penelitian ini berbunyi: Persepsi remaja tentang konflik antar orangtuanya berperan secara langsung dalam memprediksi kecemasan pada remaja. Hasil menunjukkan nilai koefisien jalur: 0.265 dengan nilai konfirmasi t: $4.730(\mathrm{t}>$ 1,96) persepsi tentang konflik antar orang tua memiliki pengaruh positif langsung yang signifikan terhadap kecemasan, sehingga hipotesis pertama diterima.

Hipotesis kedua adalah: Persepsi remaja tentang konflik antar orangtuanya berperan secara langsung dalam memprediksi depresi pada remaja. Hasil menunjukkan nilai koefisien jalur $=0,23$ dengan konfirmasi nilai $\mathrm{t}=4,81$; nilai $(\mathrm{t}$ : $>$ 1,96) dengan demikian persepsi tentang konflik antar orang tua memiliki pengaruh langsung yang signifikan terhadap depresi, sehingga hipotesis kedua, diterima .
Tabel 2. Rangkuman hasil analisis pengaruh langsung dan tidak langsung variabel persepsi terhadap konflik antar orangtua terhadap kecemasan, depresi dan resiliensi.

\begin{tabular}{|c|c|c|}
\hline Variabel & $\begin{array}{r}\text { Persepsi } t \\
\text { antar }\end{array}$ & $\begin{array}{l}\text { ntang konflik } \\
\text { orangtua }\end{array}$ \\
\hline \multirow[b]{2}{*}{ Resiliensi } & Langsung & tidak langsung \\
\hline & $\begin{array}{r}\left.-0,347^{1}\right) \\
\left.(0,119)^{2}\right) \\
\left.-2,921^{3}\right)\end{array}$ & \\
\hline Kecemasan & $\begin{array}{r}\left.0,265^{1}\right) \\
\left.(0,069)^{2}\right) \\
\left.3,862^{3}\right)\end{array}$ & $\begin{array}{r}\left.00,031^{1}\right) \\
\left.(0,0231)^{2}\right) \\
\left.1.387^{3}\right)\end{array}$ \\
\hline Depresi & $\begin{array}{r}\left.0,211^{1}\right) \\
\left.(0,045)^{2}\right) \\
\left.4,730^{3}\right)\end{array}$ & $\begin{array}{r}\left.0.009^{1}\right) \\
\left.(0.013)^{2}\right) \\
\left.0.647^{3}\right)\end{array}$ \\
\hline
\end{tabular}

Keterangan:

$\left.{ }^{1}\right)$ koefisien jalur

$\left.{ }^{2}\right)$ Standart error

$\left.{ }^{3}\right)$ nilai $t$

Hipotesis ketiga adalah:-Resiliensi berperan sebagai mediator antara persepsi remaja tentang konflik antar orangtuanya dengan kecemasan pada remaja. Hasil menunjukkan koefisien jalur $=0.031$ dan 
nilai konfirmasi $\mathrm{t}=1.387$; $(\mathrm{t}<1,96)$, hasil tersebut menunjukkan tidak ada pengaruh persepsi tentang konflik antar orangtua yang signifikan terhadap kecemasan karena dimediasi oleh resiliensi. Hasil tersebut mengindikasikan. resiliensi dapat memediasi pengaruh persepsi tentang konflik antar orangtua terhadap kecemasan. sehingga hipotesis 3 dinyatakan diterima

Hipotesis keempat yaitu: resiliensi berperan sebagai mediator antara persepsi remaja tentang konflik antar orangtuanya dengan depresi pada remaja. Hasil analisis data menunjukkan koefisien jalur $=0,009$ dan nilai konfirmasi $\mathrm{t}=0,647$; nilai $\mathrm{t}<$ 1,96, hasil tersebut menunjukkan tidak ada pengaruh persepsi tentang konflik antar orangtua yang signifikan terhadap depresi karena dimediasi oleh resiliensi. sehingga dapat disimpulkan resiliensi dapat memediasi pengaruh persepsi tentang konflik antar orangtua terhadap depresi. Dengan demikian membuktikan Hipotesis keempat dinyatakan diterima.

Hasil analisis tambahan yang menguji pengaruh langsung dari persepsi tentang konflik antar orangtua dengan resiliensi menunjukkan nilai koefisien jalur $=0.211$ dengan nilai konfirmasi $t=4.730(t>1,96)$, sehingga dapat disimpulkan ada hubungan negatif yang signifikan antara variabel persepsi tentang konflik antar orangtua dengan resiliensi.

Semua hipotesis dalam penelitian ini dinyatakan diterima dengan demikian hasil penelitian menunjukkan pesepsi remaja tentang konflik yang dialami orangtuanya secara langsung dapat berperan terhadap berkembangnya depresi dan kecemasan namun secara tidak langsung pengaruhnya tidak signifikan karena adanya faktor resiliensi yang berfungsi sebagai mediator yang menghambat berkembangnya depresi dan kecemasan.
Hasil penelitian ini mendukung hasil penelitian Esfandyary, Baharudin, \& Nowzari (2009), yang menemukan rendahnya tingkat masalah yang bersifat internal (internalizing problem) pada anak yang tumbuh dalam keluarga yang memiliki relasi keluarga yang positif dan sebaliknya anak menyaksikan konflik diantara kedua orangtuanya, mengalami berbagai masalah seperti kecemasan, depresi, rasa takut, perasaan tidak berdaya dan self esteem yang rendah. Pengaruh buruk situasi keluarga yang tidak harmonis bukan hanya membahayakan anak dan remaja dalam masa perkembangan menuju masa dewasa, namun juga dapat berpotensi untuk berkembang menjadi masalah kronik yang menimbulkan efek berkepanjangan sebagaimana yang dinyatakan oleh Amato dan Keith (Grych \& Fincham, 2001) bahwa konflik antar orangtua yang diikuti perceraian memiliki pengaruh lebih buruk bagi anak dan remaja, dibandingkan kesulitan ekonomi dan ketiadaan salah satu figur orangtua sehingga secara prospektif akan tumbuh sebagai individu yang mengalami masalah penyesuaian diri, yang akan dibawa hingga ke masa dewasa sehingga dapat menimbulkan konflik dengan pasangannya dan pengasuhan yang tidak suportif bagi anak-anaknya kelak. Berdasarkan temuantemuan tersebut maka peran resiliensi sangatlah penting karena pada penelitian ini terbukti resiliensi dapat menjadi faktor yang memediasi efek buruk konflik dalam keluarga.

Dilihat dari kategorisasi sebaran data penelitian menunjukkan sebagian besar subjek penelitian menunjukkan tingkat resiliensi dalam tingkat sedang dengan arah hubungan negatif dengan variabel kecemasan dan depresi. Sebaran data resiliensi tersebut bermakna penting karena resiliensi menunjukkan perannya dalam 
memediasi pengaruh konflik antar orangtua terhadap masalah yang bersifat internal (internalizing problems). Konflik antar orang tua merupakan faktor yang menimbulkan kerentanan sedangkan resiliensi merupakan faktor protektif. Menurut Mackay (2003) faktor protektif dan faktor kerentanan sama-sama berada dalam posisi berhadapan dengan resiko. Faktor protektif menurunkan kemungkinan terjadinya efek negatif bila dihadapkan pada resiko sedangkan faktor kerentanan meningkatkan kemungkinan terjadinya efek negatif bila dihadapkan pada resiko (Mackay, 2003). Dengan demikian konflik dalam keluarga menempatkan anak pada posisi rentan untuk mengalami berbagai masalah yang berat, sebagaimana yang dikatakan yang bersifat biologis, psikologis dan sosial yang bersifat biologis, psikologis dan sosial sumber faktor resiko utama bagi anak dan remaja Sedangkan resiliensi berperan sebagai faktor protektif yang dapat memediasi untuk menurunkan kemungkinan terjadinya resiko yang bersifat negatif sebagaimana yang disimpulkan Masten \& Powell (Luthar, 2003) dari hasil penelitiannya pada anak-anak yang bersifat biologis, psikologis dan sosial beresiko di Cambodia, bahwa akibat buruk dari kerentanan dapat diturunkan dengan meningkatkan faktor protektif yang berlaku seperti 'airbag' dalam kecelakaan mobil atau antibiotik yang melindungi dari infeksi.

Proses terbentuknya resiliensi yang bersifat dinamis digambarkan oleh Luthar dan Zelazo (Dalsell \& Swayer, 2011) bahwa resiliensi merupakan proses dinamis yang melibatkan upaya peningkatan keseimbangan antata kekuatan protektif dan kerentanan dalam berbagai kondisi beresiko dan berbagai tahap perkembangan. Gilligan (Dalsell \& Swayer, 2011) memandang resiliensi berkaitan dengan konteks lingkungan tempat individu berada, sehingga peran orang lain sangat penting dalam membentuk dan meningkatkan resiliensi anak. Oleh karena itu resileinsi pada anak dan remaja tidak dapat dilepaskan dari konteks resiliensi keluarganya dan lingkungannya. Padahal menurut Elly \& Emery (Chen \& George, 2005) konflik sendiri akan menurunkan kapasitas emosional orangtua untuk merespon kebutuhan anak, dan kebiasaan menempatkan anak pada triangulasi menyebabkan anak terjebak dalam konflik antar orangtua yang akan menimbulkan efek yang merugikan \& stres berat yang menghambat perkembangan emosi anak.

Meminimalisir efek negatif dari konflik antar orangtua menjadi satu kebutuhan yang dapat dilakukan untuk melindungi perkembangan anak dan menumbuhkan resiliensi, sehingga orangtua perlu untuk mendapatkan edukasi atau ketrampilan untuk mengelola konflik yang dihadapinya agar orangtua dapat berperan dalam melindungi anak-anaknya dari bahaya konflik dalam keluarga. Apabila dicermati pendapat Gilligan (Dalsell \& Sawyer, 2011) bahwa resiliensi berkaitan dengan konteks lingkungan tempat individu berada, maka lingkungan di luar keluarga pun dapat berperan untuk menumbuhkan resiliensi pada anak dan remaja. Dalam konteks remaja dan anak-anak yang sebagain besar menggunakan waktu yang sama panjangnya antara berada di lingkungan sekolah dan keluarga atau bahkan ada sebagian yang menggunakan waktu lebih panjang di sekolah. Menurut Henderson dan Milstein (2003), sekolah pun dapat menciptakan kondisi lingkungan yang mengembangkan reaksi-reaksi yang memungkinkan anak berkembang menjadi resilient dan menciptakan pendekatan edukasi, prevensi, dan program intervensi, serta menciptakan kurikulum untuk mengembangkan faktor 
protektif pada para siswa.

\section{Simpulan}

Diterimanya semua hipotesis penelitian menunjukkan bahwa persepsi remaja tentang konflik yang dialami kedua orangtuanya berpengaruh secara signifikan terhadap munculnya problem internal dalam bentuk depresi dan kecemasan, namun pengaruh tersebut menjadi tidak signifikan ketika dimediasi oleh resiliensi. Dengan demikian resiliensi pada anak/ remaja memainkan peran yang sangat penting dalam melindungi remaja dari berbagai efek negatif dari situasi konflik dalam lingkungan keluarganya. Konflik antar orangtua meningkatkan kerentanan remaja untuk mengalami masalah sedangkan resiliensi meningkatkan faktor protektif yang berperan menyeimbangkan dengan menurunkan kerentanan tersebut dan memberi kesempatan untuk tumbuh. Konflik antar orang tua terbukti memiliki pengaruh yang signifikan terhadap depresi dan kecemasan pada remaja. Oleh karena remaja umumnya masih berada dalam pengasuhan orangtuanya maka pemahaman tentang masalah resiliensi pada remaja tidak dapat dipisahkan dari resiliensi pada orangtuanya. Saran bagi peneliti selanjutnya adalah perlu dilakukan penyempurnaan alat ukur dengan mengujicobakan pada sampel yang lebih luas, baik dari segi rentang usia, pendidikan, etnik, maupun jumlah subjek penelitian, selanjutnya dapat dilakukan penelitian yang mendalam terutama untuk variabel persepsi tentang konflik antar orang tua dan resiliensi, sehingga dapat dikembangkan alat ukur dengan konstruk yang lebih sesuai dengan konteks budaya Indonesia.

\section{Daftar Pustaka}

Ahern, N., (1996), Resiliency in adolescent college students, Ontario : University of Delaware unpublished Dissertation

Beck, A.T. \& Alford, B.A., (2009), Depression: causes and treatment (2nd ed.), Philadelphia: University of Pennsylvania Press.

Berns, R., (2004), Child, family, school, community: socialization and support $\left(\begin{array}{ll}6^{\text {th }} & \text { ed. }\end{array}\right)$, Belmont- California:. Thomson Wadsworth.

Buehler, C., Krishnakumar,A., Anthony, C., Tittsworth,S., Stone, G. (2011), Hostile interparental conflict and youth maladjustment, Family Relations, University of Missouri, Columbia.

Chen, Jen-De dan George, R.A., (2005), Cultivating Resilience in Children From Divorce Families, The Family Journal:Counseling and therapy for Couples and Families, Vol. XX No. X, Month 2005, 1, Sage Publications.

Connolly,S., Simpson,D. \& Petty, C. (2006), Anxiety disorders, New York: Infobase Publishing.

Dalsell,R dan Sawyer, E., (2011), Putting Analysis inti Assessment: undertaking assessment of need ( 2 nd ed), London, Hobbs the Printers Ltd.

Davey,G.C.L dan Wells,A. (2006), Worry and Its Psychological Disorders, Theory, Assesssment and Treatment, West Sussex, John Wiley \& Sons Ltd.

Davern,M.T., $\quad$ Staiger,D.K., $\quad$ Luk, E.S.L.(2005), Adolescent and parental perceptions of interparental conflict; E-journal of Applied Psychology, Social Section. 1(2): 2--25 
Durand, V.M. \& Barlow, D.H. (2003), Essential of abnormal psychology (3rd ed.), California: WadsworthThomson Learning.

Esfandyary, B., Baharudin, R., dan Nowzari, L., (2009), The Relationship between Inter-parental Conflict and Externalizing Behavior Problems among Adolescents, European Journal of Social Sciences, 12, (1), 11-122

Esfandyary, B., Baharudin, R., dan Nowzari, L., (2009b), Background of inter-. arental conflict and internalizing behavior problems among adolescents, European Journal of Social Sciences, 37, (4), 599-607.

Gelles, R . J. (2011), Spouse Abuse - prevalence, theoretical explanations - Gender, Theory, Family, Definition, Violence, Women, Percent, Family, Wife, and World http://family.jrank. org/pages/1630/Spouse-Abuse. html

Glover, J., (2009), Bouncing back: How can resilience be promoted invulnerable children and young people?, http://www.barnardos.org.uk/ bouncingback_resilience_march09. pdf diakses 11 Nopember 2012.

Grych, J.H dan Fincham,F.D., (2001), Interparental conflict and child development: theory, research and applications, New York: Cambridge University Press.

Grych, J.H., Seid,M., dan Fincham,F .D., (1992), Assessing marital conflict from the child's perspective: The children's perception of interparental conflict scale, Journal of Child development, 63, 558-572

Gullotta, T.P. \& Adams G.R,. (2005), Handbook of adolescent behavioral problem: evidence-based approaches to prevention and treatment, New York : Springer Science Business edia, Inc.

Harvey, J.H. \& Wenzel, A. (Editors), (2002), A clinical's guide to maintaining and enhancing close relationships, New Jersey: Lawrence Erlbaum Associates Inc., Publishers.

Herderson, N. \& Milstein,M.M,. (2003), Resiliency in schools: making it happen for students and educators, California : Corwin Press,Inc.

Heise et.al., (2011), http://family.jrank.org/ pages/920/Interparental-ConflictEffects-on-Children-IndividualProtective-Factors.

International Encyclopedia of the Social Sciences, (2012), Encyclopedia.com. 16 Nopember $2012<$ http://www. encyclopedia.com>.

Kurcher, S. (2009), Guide to understanding adolescent major depressive disorder, , www.teenmentalhealth.org. Diakses 16 Nopember 2012.

Kurcher, S \& Chehil, S. (2009), Identification, diagnosis and treatment of adolescent depression (Major Depressive Disorder): A package for first contact health providers, $w w w$. teenmentalhealth.org. Diakses 16 Nopember 2012.

Luthar, S.S. (2003), Resilience and vulnerability: Adaptation in the context of childhood adversities, 
Cambridge : Cambridge University Press.

Mackay, R. (2003), Family Resilience and Good Child Outcomes, Social Policy Journal Of New Zealand Te Puna Whakaaro, Issue 20 June 2003, diakses 2 Oktober 2013

McDowell, I. (2006), Measuring health: a guide to rating scales and questionaires, New York: Oxford University Press.

Noyes, R.Jr. dan Hoehn-Saric,R. (2013), The anxiety disorders, London, Cambridge University Press.

Peters, R.D., Leadbeater,B. \& McMahon,R.J.(editors) (2005), Resilience in children, families and community: Linking context to practice and policy, New York: Kluwer Academic/Plenum Publishing.

Resnick, B., Roberto, K.A., \& Gwyther, L.P. (editors) (2011), Resilience and aging : conceps, research and outcomes, New York : Springer Science Business Media.
Ritvo, E.C. dan Glick, I. D. (2002), Concise Guide to Marriage and Family Therapy, Washington: American Psychiatric Publishing, Inc.

Segal, D.L., Coolidge, F.L. \& Rosowsky, E. (2006), Prsonality dsorders and older adults: diagnosis, assessment and treatment, New Jersey: John Wiley \& Sons Inc.

Solso, R.L., Maclin, O.H., dan Maclin, M. K. (2008) Psikologi kognitif(terjemahan oleh Rahardanto \& Batuadji), Jakarta: Penerbit Erlangga.

Stein,D.J., Hollander,E., dan Rothbaum,B.O. (editors), (2009), Texbook of anxiety disorders, Amarican Psychiatric Publishing,Inc. Arlington

Verduyn, C., Rogers, Y., \& Wood, A. (2009), Depression: CBT with children and young people (1st ed.), New york : Routledge.

Wicks-Nelson, R. \& Israel, A.C. (2006), Behavior disorders of childhood (6th ed.) New Jersey: Pearson Prentice Hall. 